\title{
Influence of Tourism Destination Products and Images on Tourist Visiting Decision to Kota Seribu Sungai Banjarmasin
}

\author{
Devin Cahya Triansya', Beta Budisetyorini ${ }^{2}$ \\ 'Deputi Bidang Pengembangan Industri dan Kelembagaan, Kementerian Pariwisata \\ devin.ct@halaltourism.id \\ ${ }^{2}$ Sekolah Tinggi Pariwisata Bandung \\ beta@stp-bandung.ac.id
}

\begin{abstract}
The continuous rapidly growth of tourism sector with the tight competition in the field of tourismmakes not all tourist destinations in the world always experience an increase in the number of tourist visits each year. Banjarmasin City, dubbed the "Kota Seribu Sungai" or "City of Thousand Rivers" and is known as the Thousand Rivers tourist destination has experiencedfluctuate number of tourist arrivals and tend to decline. The fluctuate number of tourist arrivalssourced from tourist visiting decisions can be influenced by various factors, including tourism destination productsand image. This study aims to see the effects of tourism destination products consisting of physical products, people, packages, and programsalsothe image of tourism destinations consisting of cognitive image and affective image on tourists visiting decision to the city of Thousand River Banjarmasin. The data obtained were taken by questionnaire to 123 tourists by accidental sampling. The results of the research were analyzed using multiple linear regression with two equations, namely (I) The influence of tourism destination products on tourist visiting decision and (II) The impact of tourism destination image on tourist visiting decision. The resultsfound the positive influence of tourism destination products to thetourist visiting decision of $54.5 \%$ and the image of tourism destination on the tourist visiting decision of $53.4 \%$ and the rest of $45.5 \%$ and $46.6 \%$ influenced by other factors not examined. The results of the analysis also showed the effect of tourism destination products variable partially consisting of physical products, packages, and programs have an effect on the decision of tourists while people have no influence. As for the variable image of tourism destinations in partial consisting of cognitive image and affective image affect the decision of tourists visiting to Kota Seribu Sungai Banjarmasin.
\end{abstract}

Keywords: destination products; Image; tourist visiting decision; Banjarmasin. 


\section{INTRODUCTION}

Tourism is a sector that continues to grow rapidly around the world. Goffi (2013: 122) said the development of international tourism has the competitiveness of intensive tourism destinations. The tight competition in the field of tourism makes not all tourist destinations in the world always experience an increase in the number of tourist visits each year. One of them is Banjarmasin City. The Capital City of South Kalimantan Province, dubbed "Kota Seribu Sungai" or "Thousand Rivers City" has a number of tourist visits that fluctuate even tended to decline, especially for foreign tourists visiting that counted from the number of their staying in the City of Banjarmasin star hotels. The decline or increase in the number of tourist visits can be influenced by various factors, including the product and the image of tourism destinations.

According to Morrison (2013), destination products are an interdependent mix of tangible and intangible components which consist of as follows:

1. Physical Product, consists of attractions, facilities (hotels, restaurants, etc.), transportation, and infrastructure.

2. People, the human resources component of the destination product consisting the personalized service provided and the simultaneuosly feeling of hospitality and welcome".

3. Packages, they considered travel or tourist packages provided by the tour operators, travel agencies, hotels, resorts, and Destination Management Organization (DMO) involvement.
4. Programs. Programming includes events, festivals, and individualized arranged activities for tourists that enhance the tourist experience in destinations. The tour program includes events, festivals, and individually arranged activities for tourists.

Morrison (2013: 94) also mentions, "The attraction and event play a key role in the destination mix, representing a unique asset of interest people to the tourist destination, and the interaction of people and visitors in the destination is an important dimension of tourism destination products.

Prideaux and Malcolm (2009:14) describe rivers are a major tourism resource providing spectacular settings, recreational opportunities, waterfront landscapes in many center of tourism interest, a means of transport and an essential source of water for human consumption. The world's great rivers have long intrigued travelers and even in ancient times provided the backdrop for travel. Based on the exposure, The City of Banjarmasin with its river tourism resources characteristic has the product and the image as a river tourism destination. Product components and image of tourism destinations are related to factors influencing travel decisions for tourists.

In addition to tourism destination products, the image of tourism destinations also plays a role in influencing the decision of visiting tourists. Morrison (2013: 409) states that "Several previous tourism research studies have shown that destination images influence the choice of tourism destination." Several previous tourism studies have shown that the image of 
the destination directly affects the choice of destination.

Cromptonin Hallman et al (2015: 95) describes the destination image as "sum of beliefs, impressions, ideas, and perceptions that people hold of objects, behaviors, and events." The image of the destination is the number of beliefs, impressions, ideas, and perceptions of people holding / feeling objects, behaviors, and events. Baloglu and McClearly in Hallman et al (2015: 95) describes the image of the destination as "an attitudinal construct of an individual's mental representations of knowledge, feelings, and global impression of an object or destination." A construction of an attitude consisting of a person's mental representation about global knowledge, feelings, and impressions about objects or destinations. According to Beerli and Martin in Morrison (2013: 409), the simultaneuosly image of the perceived destination consists of cognitive image and affective image. "The cognitive image component consists of the beliefs and knowledge about a destination, primarily focusing on tangible physical attributes". The cognitive component of the image consists of the belief and knowledge of the destination, focusing primarily on tangible physical attributes (Pike and Ryan in Hallman et al, 2015: 96). The Affective image component on the other hand represents feelings about destinations (Lin et al, Stepchenkova in Li Xing) in Hallman et al., 2015: 96).

Regarding how tourists decide to visit a tourism destination lies in the behavior of tourists. According to Ismayanti (2010: 26), every tourist has a concept of buying behavior with unique purchasing decisions because the tour is a tangiable return on investment, closely related to income and expenses, not booked instantly (except for business travelers) and involve decision planning. According to Kotler and Armstrong in Nurwitasari (2015: 94) is not just an act, but consists of several actions that include decisions about the type of product, form, brand, number of sellers, and the time and manner of payment. Six consumer decisions are made: Product Selection, Brand Option, Channel Distribution Options, Timing Option, Visits Rate, and Payment Method.

According to Mathieson and Wall in Ismayanti (2010: 30), see tourists always influenced by:

1. Tourist Profile, which includes age, education, income, previous travel experience, and motivation.

2. Awareness of travel, such as the image of facilities and services based on the credibility of the tourist destination.

3. Characteristics of tourist destinations, including tourist objects and attractions.

4. The nature of travel that includes distance, time, and travel risk.

Until now, there has not been any research conducted to proves the influence of product components and image of tourism destinations to the decision of tourists visiting The City of Banjarmasin as river tourism destination. Therefore, this research will explain how tourism destination product and image of The City of Banjarmasin as the river tourism destination, furthermore will discuss the influence of products and tourism destination image on tourist visiting decision to The Banjarmasin City of Thousand Rivers partially and simultaneously. 


\section{RESEARCH METHODOLOGY}

The research method used is explanatory research with quantitative approach. The method used by researchers to test the hypothesis of the influence of variables $X$ to variable $Y$.

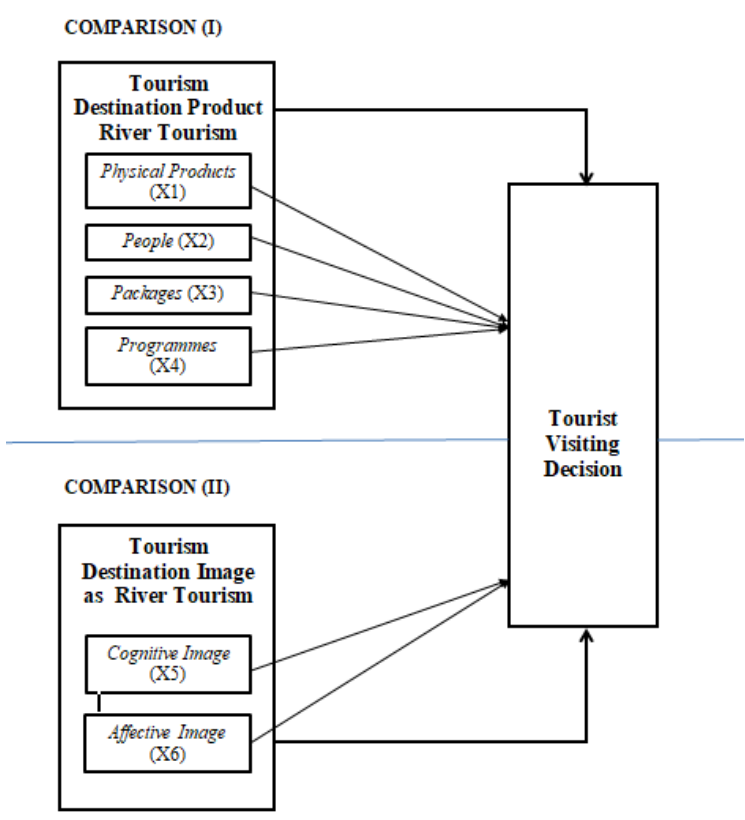

Image I. Research Paradigm

(Source : Morrison, 2013, Beerli and Martin in Morrison, 2013, Prideaux and Malcolm, 2009:14, and Kotler and Amstrong in Nurwitasari, 2015:94)

The sampling technique uses accidental sampling to take samples in the distribution of questionnaires with the number of 123 respondents. The analytical technique uses descriptive analysis to process the results of questionnaires and multiple linear regression to determine the effect of product and image of tourism destinations to the tourist visiting decision either partially or simultaneously.

\section{RESEARCH RESULT AND DISCUSSION}

Before explaining the results of research and discussion, researchers have conducted a series of tests such as validity and reliability test and assumption classical test for regression to produce valid, reliable, and BLUE (Best Linear Unbiased Estimators) data.

\section{A. Tourism Destination Products in City of Thousand River Banjarmasin}

From the data responses of tourists/respondents, seen all the indicators that become the average question - the average answer most with the answer agree. Only one indicator in the tour package exceeded expectations that the majority answered neutrally. However, in addition to these indicators, more than $50 \%$ of tourists/respondents answered Agree and Strongly Agree. In accordance with the questionnaires distributed by researchers who are positive statements, the tourism destination products consisting of physical products, people, packages, and programmes in City of Thousand River Banjarmasin can be said to be good by tourists/respondents.

\section{B. Image of Tourism Destination in City of Thousand River Banjarmasin}

From the data responses of tourists/respondents, seen all the indicators that become the question average - average answer with the answer agree and more than 50\% of tourists/respondents answered Agree and Strongly Agree. In accordance with the questionnaires distributed by researchers who are positive statements, the image of tourism destinations consisting of the cognitive image and affective image in City of Thousand River Banjarmasin can be said good by tourists/respondents 


\section{Tourist Visiting Decision to City of Thousand River Banjarmasin}

From the data responses of tourists/respondents, seen all the indicators that become the average question - the average answer most with the answer agree. However, more than $50 \%$ of travelers/respondents answered Agree and Strongly Agree. In accordance with the questionnaires distributed by the researcher which is a positive statement, the majority of tourists decided to visit tourists to Banjarmasin City by using various options/considerations, be it product selection, brand choice, distribution channel selection, choice of time, and choice of the visit.

D. Coefficient Determinant Test $\mathbf{R}^{2}$ The Influence of Tourism Destination Products on Tourist Visiting Decision to BanjarmasinCity Of Thousand River.

TABLE 1. Model Summary of Tourism Destination Products Against Visiting Decision Model Summary ${ }^{b}$

\begin{tabular}{|l|r|r|r|c|}
\hline Model & $\mathrm{R}$ & $\begin{array}{c}\mathrm{R} \\
\text { Squar } \\
\mathrm{e}\end{array}$ & $\begin{array}{c}\text { Adjusted R } \\
\text { Square }\end{array}$ & $\begin{array}{c}\text { Std. Error } \\
\text { of the } \\
\text { Estimate }\end{array}$ \\
\hline 1 &, $731^{\mathrm{a}}$ &, 534 &, 527 &, 442351 \\
\hline
\end{tabular}

(Source: Research Preparation Data , 2017)

R Square $=0.545$

R Square of 0,545 means $54,5 \%$ decision of visiting tourist influenced by product variable of tourism destination, in this case, physical product, people, packages, and programmes. The remaining $45.5 \%$ is influenced by other variables outside the model.
E. Coefficient Determinant Test $\mathbf{R}^{2}$ The Influence of Tourism Destination Image on Tourist Visiting Decision to Banjarmasin Of Thousand River.

\section{TABLE 2. Model of Tourism Destination Image Summary Against Visiting Decision}

\begin{tabular}{|l|c|r|r|r|}
\hline Model & $\mathrm{R}$ & $\begin{array}{c}\mathrm{R} \\
\text { Squar } \\
\mathrm{e}\end{array}$ & $\begin{array}{c}\text { Adjusted R } \\
\text { Square }\end{array}$ & $\begin{array}{c}\text { Std. Error } \\
\text { of the } \\
\text { Estimate }\end{array}$ \\
\hline 1 &, $738^{\mathrm{a}}$ &, 545 &, 529 &, 441139 \\
\hline
\end{tabular}

(Source: Research Preparation Data , 2017)

$$
\text { R Square }=0,534
$$

R Square equal to 0,534 means $53,4 \%$ tourist visiting decision influenced by the variable of the image of tourism destination, in this case, cognitive image and affective image. The remaining $46.6 \%$ is influenced by other variables outside the model.

\section{F. Partial Test (t-test)}

From the results of calculations that have been obtained, a partial test or ttest to determine how the influence of each independent sub-variables of two equations, namely:

a. Product Destination Sub-variable consisting of Physical Product, People, Packages, Programs on visiting tourist decision, with the hypothesis:

$\mathrm{Ho}=$ Tourism Destination Sub-variable consisting of Physical Product, People, Packages, Programs have no influence on tourist visiting decision.

$\mathrm{Ha}=$ Product Destination Sub-variable of Tourism consisting of Physical Product, People, Packages, Programs have an influence on tourist visiting decision. 
TABLE 3

t-table and t-count Tourism Destination Products Against Visiting Decision

\begin{tabular}{|l|l|r|l|}
\hline No & Sub-Variable & t-table & t-count \\
\hline 1 & $\begin{array}{l}\text { Physical } \\
\text { Product }\end{array}$ & 3,691 & \multirow{2}{*}{1,98027} \\
\cline { 1 - 2 } 2 & People & 1,399 & \multirow{2}{*}{3,539} \\
\cline { 1 - 2 } 3 & Packages & 3,096 & \\
\cline { 1 - 2 } 4 & Programmes & \multicolumn{2}{|c|}{} \\
\hline
\end{tabular}

The t-table results of Physical Product, Packages, and Programs Sub-variables exceeded the t-count so that subvariables of tourism destination products partially consisting of Physical Product, Packages, and Programs influenced the decision of tourists visiting Banjarmasin City Of Thousand River. While the sub-variable People does not affect the decision of visiting tourists.

b. Sub-variable of Tourism Destination Image consisting of Cognitive Image \& Affective Image on visiting tourist decision, with hypothesis:

$\mathrm{Ho}=$ Sub-variable Tourism Destination Image consisting of Cognitive Image and Affective Image have no influence on tourist visiting decision.

$\mathrm{Ha}=$ Sub-variable Image of Tourism Destination consisting of Cognitive Image and Affective Image influence on tourist visiting decision.
TABLE 4

t-table and t-count of Tourism Destination Image on Visiting Decision

\begin{tabular}{|l|l|c|c|}
\hline No & Sub-Variable & t-table & t-count \\
\hline 1 & $\begin{array}{l}\text { Cognitive } \\
\text { Image }\end{array}$ & 6,640 & \multirow{2}{*}{3,97993} \\
\hline 2 & $\begin{array}{l}\text { Affective } \\
\text { Image }\end{array}$ & 3,000 & \\
\hline \multicolumn{3}{|l|}{ (Source: Research Preparation Data, 2017) }
\end{tabular}

The $\mathrm{t}$-table sub-variables of Cognitive Image and Affective Image exceed the tcount so that the sub-variables of tourism destination image partially consisting of Cognitive Image and Affective Image affect the decision of visiting tourists to the Of Thousand River Banjarmasin.

\section{G. F-test}

Test-F Stat or F-Test is used to find out whether the independent variables in the regression equation affect the dependent variable simultaneously with a certain level of significance. In this research, the researcher makes two Ftest that is tourism destination product variable which consists of Physical Product, People, Packages, and Programmes as a whole influential to tourist visiting decision and tourism destination image variable consisting of Cognitive Image and Affective Image as a whole have an effect against the tourist visiting decision. 
TABLE 5

\section{F-table and F-count Product and Tourism Destination Image to Visiting Decision}

\begin{tabular}{|l|l|c|c|}
\hline No & Sub-Variable & F-table & $\begin{array}{l}\text { F- } \\
\text { count }\end{array}$ \\
\hline 1 & $\begin{array}{l}\text { Tourism } \\
\text { Destination } \\
\text { Products }\end{array}$ & 35,273 & 2,45 \\
\hline 2 & $\begin{array}{l}\text { Tourism } \\
\text { Destination } \\
\text { Images }\end{array}$ & 68,836 & 2,68 \\
\hline
\end{tabular}

(Source: Research Preparation Data , 2017)

From the table results obtained:

F-table of product variables of tourism destinations exceed F-count so as to influence the decision of tourists visiting the city of Thousand River Banjarmasin

2. F-table of tourism destination image variable exceeds F-count so as to influence the tourist visiting decision to the city of Thousand River Banjarmasin.

\section{CONCLUSIONS AND SUGGESTIONS}

\section{A. Conclusion}

Based on the results of the analysis that has been done, it can be concluded that:

1. Tourism Destination Products consisting of Physical Product, People, Packages, and Programs in the city of Thousand River Banjarmasin is a good value based on the response of tourists where the majority of tourists rate agree and strongly agree.

2. Tourism Destination Image consisting of Cognitive Image and Affective Image in the City of Thousand River Banjarmasin is good value based on tourist response where the majority of tourists/respondents rate agree and strongly agree.
3. The tourist visiting decision to the city of Thousand River Banjarmasin is determined by using various options/considerations, including product selection, brand choice, distribution channel choice, time choice, and choice of visit based on tourist response where the majority of tourists rate agree and strongly agree.

4. Partially, not all dimensions of tourism destination products that affect the decision of tourists visiting the city of Thousand River Banjarmasin. From the results of data processing, the dimensions of the people have no influence on the decision variable of tourists visiting, while simultaneuosly there is a positive influence of the four dimensions of tourism destination products on the decision of visiting tourists to the city of Thousand River Banjarmasin.

5. Partially and simultaneuosly there is a positive influence of the two dimensions of the image of tourism destinations are cognitive image and affective image of the decision to visit tourists to the city of Thousand River Banjarmasin.

\section{B. Suggestions}

1. Improvement of Tourism Products and Image City of Thousand Rivers Banjarmasin

a. The government is expected to continue to improve the products of tourism destinations, especially in terms of people and the image of tourism destinations Banjarmasin as a tourist destination of the river to increase tourist visits.

b. The government is expected to start planning tourism both 
from the side of the destination and marketing because based on the response of tourists on average - assume the product and image of tourism destination of Banjarmasin city is good but tourist visit to Banjarmasin city fluctuate even tends to decrease.

c. The government is expected to increase the tour package, especially the river tour in Banjarmasin such as adding the boat / klotok schedule and renovating the ship / klotok so it has a unique and unique shape.

d. The travel agent is expected to make a river tour package in Banjarmasin City in more detail (not only to floating market only) but other river tourism attractions such as visiting riverside museums, seeing the life of river banks directly, visiting historic buildings, and others.

e. The community is expected to always maintain cleanliness, especially the cleanliness of the existing river in the city of Banjarmasin to be more attractive for tourists to visit.

\section{Further research}

a. The decision to visit Banjarmasin City in this study only examines the effect of product and image of tourism destination of Banjarmasin City from the side of tourist perception and still needs further study outside product variable and tourism destination image. This is because there are still 45,5\% (Regression Equation I: Tourism Destination Product Effect) and 46,6\% (Regression
Equation II: Tourism Destination Imagery) visiting decision to City Of Thousand River Banjarmasin which still influenced by other variables as sample of mix marketing and competitiveness such as the concept of Ritchie \& Crouch (2003), or other variables that are not part of this research.

b. Conducting research with other analysis about product and image of tourism destination in City of Thousand River Banjarmasin like using quantitative approach with SEM (Structural Equation Modeling) or using qualitative approach to create research variation.

c. Conducting other market studies with foreign tourist respondents.

\section{REFERENCES}

Agapito, Dora et al. (2013). The CognitiveAffective-Conative Model of Destination Image: A Confirmatory Analysis. Journal of Travel \& Tourism Marketing. Vol. 30. No. 5. P1-27).

Agung, I Gusti Ngurah. (2014). Manajemen Penyajian Analisis Data Sederhana. Jakarta : PT RajaGrafindo Persada.

Arifin, Zainal. (2011). Penelitian Pendidikan:Metode dan Paradigma Baru. Bandung : PT Remaja Rosdakarya.

Arikunto, Suharsimi. (2002). MetodologiPenelitian. Jakarta : Rineka Cipta.

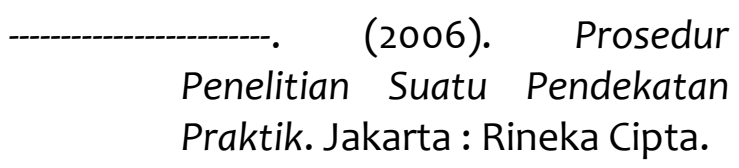


Budiaji, Weksi. (2013). Skala Pengukuran dan Jumlah Respon Skala Likert. Jurnal Ilmu Pertanian dan Perikanan. Vol. 2. No. 2. p127133.

Bungin, Burhan. (2005). Metode Penelitian Kuantitatif. Jakarta : Kencana Prenada Media.

Cresswell, John W. (2003). Research Design : Qualitative, Quantitative and Approached. California : Sage Publication, Inc.

Crotti, Roberto \& Tiffany Misrahi (Ed). (2015). The Travel \& Tourism Competitiveness Report 2015. Geneva : World Economic Forum (WEF).

Dinas Kebudayaan dan Pariwisata Kota Banjarmasin 2017

Ghony, Junaidi \& Fauzan Almanshur. (2012). Metode Penelitian Kualitatif. Yogyakarta : ARRuzz Media.

Ghozali, Imam. (2012). Aplikasi Analisis Multivariat dengan SPSS. Semarang : Badan Penerbit FE UNDIP.

Goffi, Gianluca. (2013). A Model Of Tourism Destination Competitiveness: The Case Of The Italian Destinations of Excellence. Jurnal Anuario Turismo $y$ Sociedad. Vol. 14. p121-147.

Gujarati, Damodar. (2003). Basic Econometrics, Fourth Edition. New York : McGraw-Hill.

(2012). Econometrics by Example. New York : Palgrave Macmillan,
Gunawan, Imam. (2016). Pengantar Statistika Inferensial. Jakarta : PT Rajagrafindo Persada.

Hallman, Kirstin et al. (2015). Perceived Destination Image : An Image Model for a Winter Sports Destination and Its Effect on Intention to Revisit. Journal of Travel Research. Vol. 54. No. 1. p94-106

Hapsari, Nurul Retno et al. (2014). Pengaruh Atribut Produk Wisata dan Electronic Word of Mouth (Ewom) terhadap Keputusan Berkunjung pada Obyek Wisata Umbul Sidomukti Kabupaten Semarang. Jurnal Ilmu Administrasi Bisnis. Vol. 3. No. 4. p249-259.

Hermawan, Asep. (2009). Penelitian Bisnis. Jakarta : Grasindo.

Ismayanti. (2010). PENGANTAR PARIWISATA. Jakarta : Grasindo.

Mahadewi, Ni Made Eka. (2012). Atraksi, Produk Wisata, dan Event Wisata dari Teori ke Praktik. Jurnal Perhotelan dan Pariwisata. Vol. 2. No. 1. p1-10).

Margono, Drs S. (2004). Metode Penelitian Pendidikan. Jakarta : Rineka Cipta.

Morrison, Alastair M. (2013). Marketing and Managing Tourism Destination. London : Routledge.

Nawawi. Hadari. (2001). Manajemen Sumber Daya Manusia untuk Bisnis yang Kompetitif. Yogyakarta : Gajah Mada University Press.

Nazir, Moh. (2014). Metode Penelitian. Bogor: Ghalia Indonesia. 
Nuriata. (2014). Paket Wisata Penyusunan Produk dan Penghitungan Harga. Bandung : Alfabeta.

Nurwitasari, Ayu. (2015). Pengaruh Wisata Gastronomi Makanan Tradisional Sunda terhadap Keputusan Wisatawan Berkunjung ke Kota Bandung. Jurnal Barista. Vol. 2. No. 1. P92-102.

Prideaux, Bruce \& Malcolm Cooper. (2009). River Tourism. London : CAB International.

Priyanto, Rizky, et al. (2016). Pengaruh Produk Wisata, Destination Image, dan Word of Mouth Terhadap Keputusan Berkunjung (Studi Kasus pada Pengunjung Objek Wisata Goa Kreo Semarang). Jurnal Ilmu Administrasi Bisnis. Vol. 5. No. 1. p217-226).

Pro Kalimantan Selatan managed by Radar Banjarmasin. (2016). Banjarmasin TARGETKAN 1 JUTA WISATAWAN DALAM SETAHUN. Diambil dari website : http://kalsel.prokal.co/read/news/ 4676-banjarmasin-targetkan-1juta-wisatawan-dalamsetahun.html.

Radisic, Branka Berc. (2010). Marketing Activities in Selling a Destination's Tourism Product. Jurnal Tourism \& Hospitality Management 2010. Pp765-770

Ritchie, J.R. Brent \& Geoffrey I. Crouch. (2003). The Competitive Destination A Sustainable Tourism Perspective. Cambridge : $\mathrm{CABI}$ Publishing.

Sandjojo, Nidjo. (2011). Metode Analisis Jalur (Path Analysis) dan
Aplikasinya. Jakarta : Pustaka Sinar Harapan

Sarwono, Jonathan. (2006). Metode Penelitian Kuantitatif dan Kualitatif. Yogyakarta : Graha IImu.

Simamora, Bilson. (2002). Panduan Riset Perilaku Konsumen. Surabaya : Pustaka Utama.

Soewadji, Jusuf. (2012). Pengantar Metodologi Penelitian. Jakarta : Mitra Wacana.

Sulistiyana, Rizki Teguh, et al. (2015). Pengaruh Fasilitas Wisata dan Harga terhadap Kepuasan Konsumen (Studi pada Museum Satwa). Jurnal Administrasi Bisnis / JAB. Vol. 25. No. 1. p1-9.

Suryadana, M. Liga \& Vanny Octavia (2015). Pengantar Pemasaran Pariwisata. Bandung : Alfabeta.

Statistik Daerah Kota Banjarmasin 2014 2015 2016

Tjiptono, Fandy. (2008). Strategi Pemasaran. Yogyakarta : Andy Offset.

Umar, Husein. (2005). Metode Penelitian Untuk Skripsi dan Tesis Bisnis. Jakarta : Grafindo.

Wahdiniwaty, Rahma. (2013). Aksesibilitas Wisata pada Kota Metropolitan di Negara Berkembang (Studi Survey di Wilayah Bandung Raya). Jurnal Majalah Ilmiah UNIKOM. Vol.11. No.2. p200-209. 
Yoeti, Oka A. (2001). Ilmu Pariwisata : Sejarah, Perkembangan, dan Prospeknya. Jakarta: Pertja.

Zakia, Sheila Zara, et al. (2016). Pengaruh Produk Wisata, dan Word of
Mouth terhadap Keputusan Berkunjung dengan Citra Destinasi sebagai Variabel Intervening (Studi pada Obyek Wisata Colo Kudus). Jurnal Administrasi Bisnis. Vol. 5. No. 4. p510- 518. 